\title{
Penggunaan Teknologi Guru Dalam Jabatan Melalui Kerangka Kerja Technological Pedagogical Content Knowledge (TPACK)
}

\author{
Nazaruddin Ali Basyah ${ }^{1}$, Irham Fahmi ${ }^{2}$ dan Zakaria A. Jalil ${ }^{3}$ \\ ${ }^{1,2,3}$ Universitas Syiah Kuala, Banda Aceh, Indonesia \\ e-mail: nazar@unsyiah.ac.id
}

Received: 04 March 2021; Revised: 26 April 2021; Accepted: 28 August 2021

DOI: http://dx.doi.org/10.37905/aksara.7.3.1245-1250.2021

\begin{abstract}
ABSTRAK
Kajian ini membahas hambatan pencapaian guru dalam jabatan terhadap integrasi teknologi, dengan menggunakan prinsip-prinsip Technological Pedagogical Content Knowledge (TPACK) sebagai kerangka evaluatif. Analisis data berdasarkan interaksi antar komponen inti TPACK mengungkapkan bahwa peserta kesulitan mengembangkan pengetahuan baru. Kurangnya pengalaman pedagogis membatasi pengembangan pendekatan integrasi teknologi yang tepat. Membuat basis pengetahuan baru berdasarkan komponen pengajaran yang berbeda bisa jadi sulit bagi guru dalam jabatan karena membutuhkan pemahaman yang mendalam tentang pengetahuan inti dan interpretasi konteks pengajaran dan dinamikanya. Mengembangkan Pedagogical Content Knowledge (PCK) merupakan faktor sangat penting dalam integrasi teknologi secara keseluruhan; para guru harus memprioritaskan untuk memperoleh PCK sebelum mengintegrasikan teknologi. Dalam pendidikan calon guru profesi, pengembangan PCK harus didukung dengan pengalaman mengajar yang sebenarnya. Hasil kajian dapat memberikan wawasan yang berharga sehubungan dengan fokus yang tepat pada integrasi teknologi dan mengenali batasan dan tantangan dalam prinsip TPACK untuk mereka yang mengintegrasikan teknologi dalam mengajar dan mereka yang merancang aktivitas berbasis TPACK.
\end{abstract}

Kata Kunci: Guru, teknologi, pedagogi, pengetahuan

\section{PENDAHULUAN}

Teknologi telah menjadi bagian yang semakin penting dalam kehidupan pelajar di luar sekolah, dan bahkan di dalam kelas juga dapat membantu meningkatkan pemahaman mereka tentang konsep-konsep kompleks atau mendorong kolaborasi di antara teman sebaya. Oleh karena manfaat ini, praktik pendidikan saat ini menunjukkan bahwa guru menerapkan beberapa bentuk teknologi di ruang kelas mereka tetapi banyak guru menghadapi kesulitan dalam melakukannya. Biaya, akses, dan waktu sering menjadi hambatan yang cukup besar untuk diimplementasikan di dalam kelas, tetapi kendala lain adalah kurangnya pengetahuan tentang bagaimana teknologi dapat digunakan untuk memberi manfaat terbaik bagi pelajar dalam berbagai mata pelajaran. 
Jika guru ingin menggunakan kembali alat dan mengintegrasikannya ke dalam pengajaran mereka, mereka membutuhkan jenis pengetahuan khusus yang disebut Technological Pedagogical Content Knowledge (TPACK). Kekurangan pengetahuan tentang masalah pedagogis inti, seperti pemahaman siswa, lintasan perkembangan mereka, kesalahpahaman konseptual yang mungkin mereka miliki, dan cara terbaik untuk mempresentasikan ide kepada siswa secara individu. Pengajaran berkualitas, merupakan transformasi materi dan tindakan mengajar dengan penuh disiplin. Mengajar bukanlah proses mengambil beberapa teknik instruksional dan menerapkannya. Ia muncul dari memikirkan secara mendalam tentang sifat dan disiplin dan juga hubungannya dengan strategi untuk membantu siswa mempelajarinya dari waktu ke waktu. Dengan kata lain, PCK adalah sejenis pengetahuan yang berjalan di luar pengetahuan tentang materi atau tentang pedagogi yang diambil secara terpisah. Pengajaran membutuhkan transformasi materi dengan cara yang membuatnya dapat diakses oleh siswa. Perubahan pesat dalam teknologi telah menambahkan jenis pengetahuan baru, guru harus berintegrasi dengan pedagogis dan pengetahuan materi.

\section{KAJIAN PUSTAKA}

Kerangka kerja TPACK Mishra dan Matthew J. Koehler (2006), yang berfokus pada pengetahuan teknologi (TK), pengetahuan pedagogis (PK), pengetahuan materi $(\mathrm{CK})$, dan menawarkan pendekatan produktif terhadap banyak dilema yang dihadapi para guru dalam menerapkan teknologi pendidikan (edtech) di ruang kelas mereka. Dengan membedakan antara ketiga jenis pengetahuan ini, kerangka kerja TPACK menguraikan bagaimana konten (apa yang diajarkan) dan pedagogi (bagaimana guru menanamkan materi) harus membentuk fondasi bagi setiap integrasi edtech yang efektif. Urutan ini penting karena teknologi yang diterapkan harus mengkomunikasikan konten dan mendukung pedagogi untuk meningkatkan pengalaman belajar siswa.

Kekurangan pengetahuan tentang masalah pedagogis inti, seperti pemahaman siswa, lintasan perkembangan mereka, kesalahpahaman konseptual yang mungkin mereka miliki, dan cara terbaik untuk mempresentasikan ide kepada siswa secara individu. Pengajaran berkualitas, merupakan transformasi materi dan tindakan mengajar dengan penuh disiplin. Mengajar bukanlah proses mengambil beberapa teknik instruksional dan menerapkannya. Ia muncul dari memikirkan secara mendalam tentang sifat dan disiplin dan juga hubungannya dengan strategi untuk membantu siswa mempelajarinya dari waktu ke waktu. Dengan kata lain, PCK adalah sejenis pengetahuan yang berjalan di luar pengetahuan tentang konten atau tentang pedagogi yang diambil secara terpisah. Pengajaran membutuhkan transformasi materi dengan cara yang membuatnya dapat diakses secara oleh siswa. Perubahan pesat dalam teknologi telah menambahkan jenis pengetahuan baru, guru harus berintegrasi dengan pedagogis dan pengetahuan materi.

Literatur pendidikan terbaru telah mengakui TPACK sebagai jenis pengetahuan yang berbeda dan dibutuhkan untuk desain pembelajaran terintegrasi TIK. Mishra dan Koehler (2006) berpendapat bahwa TPACK dibuat ketika guru menggunakan pengetahuan teknologi, pengetahuan pedagogis, dan pengetahuan materi mereka untuk membuat strategi integrasi TIK yang spesifik. Strategi integrasi TIK Guru mencerminkan pertimbangan mereka terhadap materi, pedagogi, karakteristik peserta didik, dan teknologi dalam kaitannya dengan konteks sekolah dan kelas (Angeli dan Valanides 2009). Studi empiris telah menemukan TPACK merupakan sejenis pengetahuan yang muncul saat guru terlibat dalam desain pelajaran terintegrasi TIK (Koehler et al. 2007). Mishra dan Koehler (2006) berteori bahwa TPACK guru muncul melalui koneksi di antara berbagai bentuk pengetahuan. Misalnya, guru dapat mengembangkan pengetahuan pedagogi teknologi 
(TPK) sebagai perantara sumber pengetahuan untuk menghubungkan pengetahuan teknologi (TK) dengan pengetahuan pedagogik (PK), dan TPK pada gilirannya dapat disinkronkan dengan pengetahuan materi (CK). untuk membentuk TPACK.

Studi berdasarkan kerangka kerja TPACK yang diteorikan oleh Mishra dan Koehler telah menemukan bahwa kepercayaan yang dirasakan guru untuk sumber pengetahuan perantara seperti TPK dan pengetahuan konten teknologi (TCK) adalah prediktor positif yang signifikan dari kepercayaan yang mereka rasakan untuk TPACK (Chai et al. 2013) . Studi yang tidak dapat memvalidasi struktur faktor TPACK berpendapat bahwa konstruksi TPACK individu tidak mudah dibedakan oleh guru karena TPACK memiliki sifat transformatif, yang ada sebagai bentuk pengetahuan yang unik (Archambault \& Barnett 2010). Sebaliknya, pandangan integratif melihat TPACK sebagai sintesis dari komponen pengetahuan yang berbeda daripada bentuk pengetahuan baru (Angeli \& Valanides 2009). Sementara validasi statistik kerangka TPACK dan sifat epistemologisnya masih diteliti, kelemahan yang lebih mendesak dari kerangka kerja adalah kontribusi praktisnya terhadap desain pelajaran yang lebih baik oleh guru (Cox \& Graham 2009). Sampai saat ini, sedikit yang dipahami tentang bagaimana guru dapat mengubah berbagai bentuk TPACK serta pengetahuan kontekstual mereka menjadi desain pelajaran terintegrasi TIK yang baik. Konsepsi pemikiran desain dapat meningkatkan celah kerangka kerja TPACK ini.

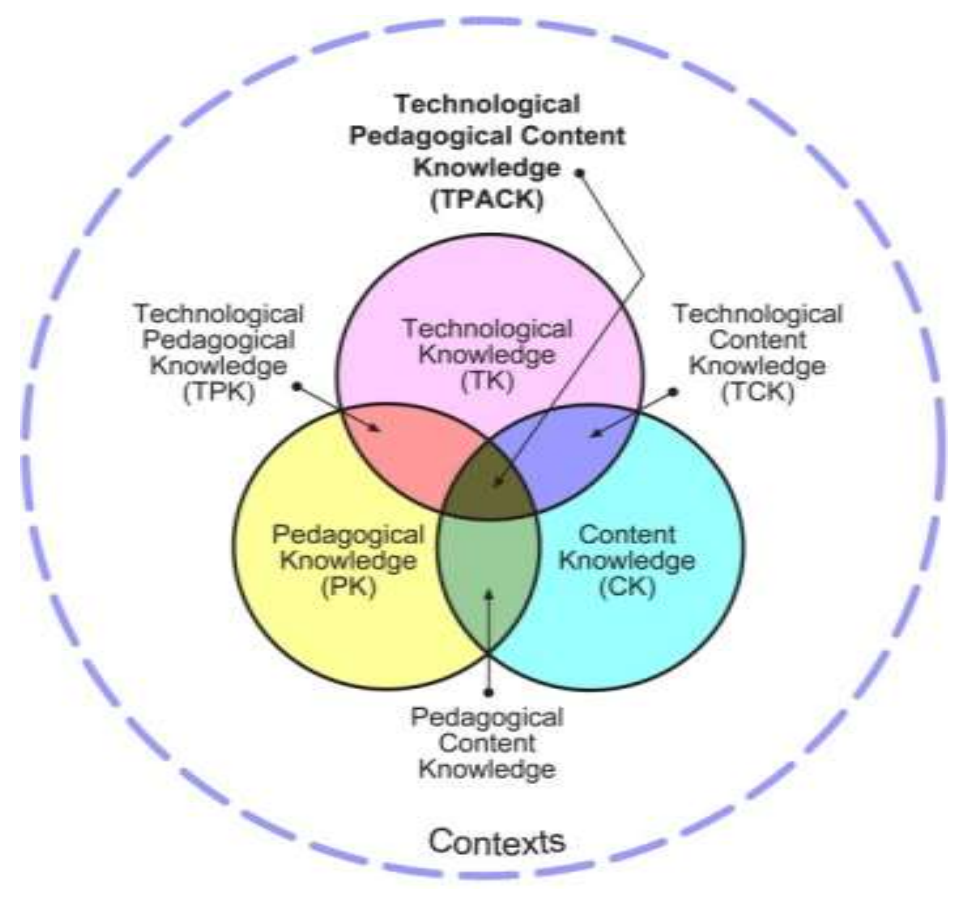

Oleh karena itu mempertimbangkan berbagai jenis pengetahuan yang dibutuhkan dan bagaimana guru sendiri dapat mengembangkan pengetahuan ini, kerangka kerja TPACK dengan demikian menjadi cara yang produktif untuk mempertimbangkan bagaimana guru dapat mengintegrasikan teknologi pendidikan ke dalam kelas. TPACK juga dapat berfungsi sebagai pengukuran pengetahuan instruktur, yang berpotensi mempengaruhi pelatihan dan penawaran pengembangan profesional untuk guru di semua tingkat dan pengalaman. 


\section{PEMBAHASAN}

Pada tahap pertama, kegiatan untuk berkembangnya pemahaman tentang konten TPACK (CK, PK, TK, PCK, TCK, TPK, TPACK) dapat diimplementasikan. Sebagai contoh, dalam bidang pengetahuan tentang materi pelajaran, peserta mendalami kurikulum nasional dan berdiskusi penggunaan teknologi untuk mengajarkan topik yang berbeda dalam kurikulum itu. Perkembangan TK itu difokuskan pada fase kedua mata pelajaran, dan ini pada intinya, beberapa teknologi pembelajaran disajikan kepada para siswa. Alat-alat ini dapat dikategorikan menjadi: 1) multimedia (grafik, audio, video, dan animasi 2D / 3D); 2) alat presentasi (seperti Microsoft Power Point); 3) alat kolaborasi (seperti Google Docs dan Youtube); dan 4) alat web 2.0 (seperti Web Quest). Siswa diberi tahu bahwa mereka tidak hanya akan belajar tentang teknologi tetapi juga bagaimana menggunakan teknologi dalam kegiatan mengajar. Selama fase terakhir mata pelajaran, bertujuan untuk meningkatkan TPACK siswa, siswa berpartisipasi dalam contoh kegiatan ekonomi yang diperkaya teknologi; kemudian setiap siswa guru didorong untuk mempersiapkan rencana pelajaran ekonomi yang diperkaya teknologi untuk mengajar untuk 1-2 periode di sekolah, ajarkan, dan renungkan implementasinya. Struktur kursus berbasis TPACK ditunjukkan pada Gambar 1:

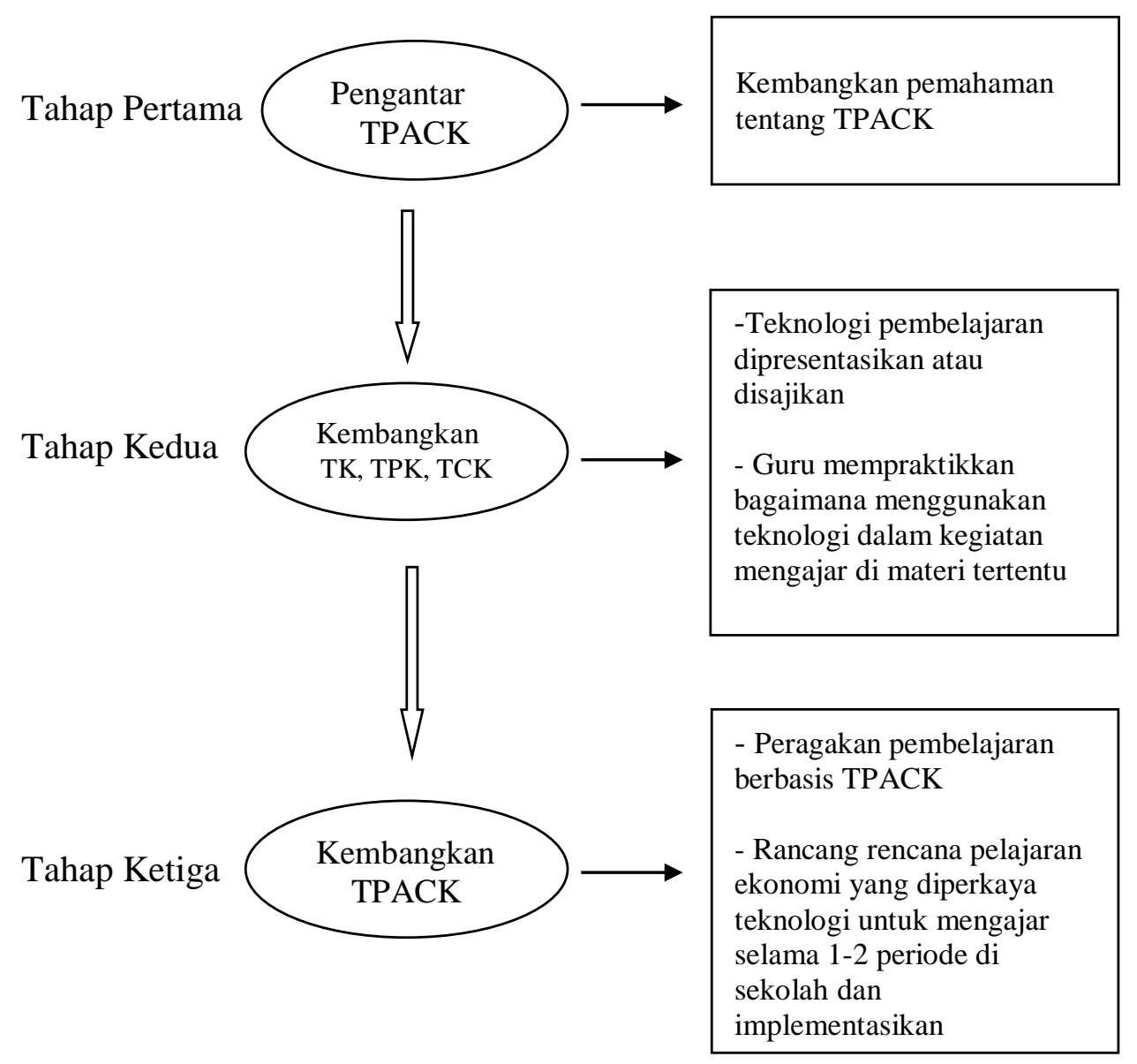

Gambar 1 : Struktur mata pelajaran berbasis TPACK

Pelajaran ekonomi yang diperkaya teknologi rencana disiapkan dan dilaksanakan oleh setiap peserta di tahap terakhir mata pelajaran dianalisis untuk menentukan caranya bagaimana menerapkan metode pengajaran yang inovatif dan strategi untuk praktik 
pengajaran mereka. Data dari RPP dianalisis menggunakan analisis induktif untuk membangun pola makna dari data (McMillan \& Schumacher, 2001). Empat fase, seperti yang dijelaskan oleh McMillan dan Schumacher, digunakan untuk analisis rencana pelajaran: 1) menerapkan penemuan terus-menerus, penelitian untuk mengidentifikasi pola secara tentatif; 2) mengkategorikan dan memesan data; 3) memperbaiki pola dengan menentukan tingkat kepercayaan data; dan (4) menyelaraskan tema-tema.

\section{SIMPULAN}

TPACK adalah hasil akhir dari berbagai kombinasi dan minat, dari tiga bidang yang mendasari materi, pedagogi, dan teknologi, untuk menciptakan dasar yang efektif dalam pengajaran menggunakan teknologi pendidikan. Guru dapat menggunakan kerangka kerja TPACK secara efektif, mereka harus terbuka terhadap ide-ide kunci tertentu, termasuk: konsep dari materi yang diajarkan dapat direpresentasikan menggunakan teknologi, teknik pedagogis dapat mengkomunikasikan materi dengan berbagai cara menggunakan teknologi, konsep konten yang berbeda memerlukan tingkat keterampilan yang berbeda dari siswa, dan agar dapat membantu mengatasi beberapa persyaratan, pelajar datang ke kelas dengan latar belakang yang berbeda, termasuk pengalaman pendidikan sebelumnya dan paparan teknologi dan juga pelajaran yang memanfaatkan tehnologi harus menjelaskan kemungkinan ini, teknologi pendidikan dapat digunakan bersamaan dengan pengetahuan pelajar yang ada, membantu mereka memperkuat epistemologi sebelumnya atau mengembangkan yang baru. Akhirnya, kerangka kerja TPACK berguna untuk cara-cara di mana ia menjelaskan jenis-jenis pengetahuan yang paling dibutuhkan untuk membuat integrasi teknologi berhasil di kelas. Guru bahkan tidak perlu terbiasa dengan seluruh kerangka kerja TPACK untuk mendapatkan manfaat darinya: mereka hanya perlu memahami bahwa praktik pengajaran terbaik dibentuk oleh pengetahuan yang didorong oleh materi, baik secara pedagogis, dan berpikiran maju secara teknologi.

\section{DAFTAR PUSTAKA}

Archambault, L. M., \& Barnett, J. H. (2010). Revisiting technological pedagogical content knowledge: Exploring the TPACK framework. Computers \& Education, 55(4), 1656-1662.

Angeli, C., \& Valanides, N. (2009). Epistemological and methodological issues for the conceptualization, development, and assessment of ICT-TPCK: Advances in technological pedagogical content knowledge (TPCK). Computers \& education, 52(1), 154-168.

Chai, C. S., Koh, J. H. L., \& Tsai, C. C. (2013). A review of technological pedagogical content knowledge. Journal of Educational Technology \& Society, 16(2), 31-51.

Cox, S., \& Graham, C. R. (2009). Using an elaborated model of the TPACK framework to analyze and depict teacher knowledge. TechTrends, 53(5), 6069.

McMillan, J. H., \& Schumacher, S. (2001). Research in education: A conceptual introduction. Little, Brown.

Mishra, P., \& Koehler, M. J. (2006). Technological pedagogical content knowledge: A framework for teacher knowledge. Teachers college record, 108(6), 1017- 
1054.

Koehler, M. J., Mishra, P., \& Yahya, K. (2007). Tracing the development of teacher knowledge in a design seminar: Integrating content, pedagogy and technology. Computers \& Education, 49(3), 740-762. 